Revue

de Sémantique

et Pragmatique
Revue de Sémantique et Pragmatique

40 | 2016

Exclamation et intersubjectivité

\title{
The deictic dimension of exclamations: On the use of wh-exclamatives in German face-to-face interaction
}

\section{Martin Pfeiffer}

\section{(2) OpenEdition \\ Journals}

Electronic version

URL: http://journals.openedition.org/rsp/288

DOI: $10.4000 /$ rsp. 288

ISSN: $2610-4377$

Publisher

Presses universitaires d'Orléans

\section{Printed version}

Date of publication: 1 March 2017

Number of pages: $35-57$

ISSN: 1285-4093

\section{Electronic reference}

Martin Pfeiffer, «The deictic dimension of exclamations: On the use of wh-exclamatives in German face-to-face interaction », Revue de Sémantique et Pragmatique [Online], 40 | 2016, Online since 01 March 2018, connection on 30 April 2019. URL : http://journals.openedition.org/rsp/288 ; DOI : $10.4000 /$ rsp.288 


\title{
THE DEICTIC DIMENSION OF EXCLAMATIONS: ON THE USE OF WH-EXCLAMATIVES IN GERMAN FACE-TO-FACE INTERACTION
}

\author{
Martin Pfeiffer \\ Department of German Linguistics, University of Freiburg
}

\section{EXCLAMATIONS FROM AN INTERSUBJECTIVE PERSPECTIVE}

Exclamations are a well-established object of research in linguistics. To date, they have mainly been conceived of as syntactic phenomena, that is, from the perspective of 'exclamative sentences'. Exclamative sentences are commonly understood as "sentences in which a speaker expresses in a non-propositional way that a state of affairs described in the sentence does not correspond to his expectations about the world" (d'Avis 2013: 171, translation MP). In research on German, the question of whether exclamative utterances constitute a sentence type in their own right (cf. Zaefferer 1983; Altmann 1987; Näf 1987; Batliner 1988; Oppenrieder 1988; Schwabe 1992) or are rather to be seen as a specific manner of use of other underlying sentence types (cf. Fries 1988; Rosengren 1992, 1997; d'Avis 2001) has been at the center of syntactic research interests and remains controversial. However, there is consensus that certain syntactic structures are used for expressing exclamativity and have certain describable properties (cf. d'Avis 2013: 174). In German, the main syntactic formats typically distinguished in the literature (cf. Altmann 1993; Zifonun et al. 1997: 671-675) are as follows (the right column reflects the word order of the different German formats which can all be translated 'How tall she is!'): 
1. V1-exclamative

2. V2-exclamative

3. That-exclamative

4. Wh-V2-exclamative

5. Wh-VL-exclamative
Ist DIE aber groß!

DIE ist aber groß!

Dass DIE so groß ist!

Wie ist DIE groß!

Wie GROSS die ist!
Is she \{modal particle\} tall!

She is \{modal particle\} tall!

That she so tall is!

How is she tall!

How tall she is!

As the examples show, the group of exclamative formats is heterogeneous with regard to syntax: we can find the verb in first (V1, format 1), second (V2, formats 2 and 4), and last (VL, formats 3 and 5) position. Exclamatives can occur with modal particles that support the expression of speaker stance (e.g. aber in formats 1 and 2), but there are certain restrictions on which particle can occur in which format (e.g. ja can occur in V2-exclamatives only, cf. d'Avis 2013: 174). Furthermore, these syntactic formats can be preceded by facultative elements, such as interjections (e.g. boah). An important prosodic feature of exclamatives that combines with the syntactic level is the so-called exclamative accent (shown in capitals in the examples). The position of this accent can vary, but it is often found on constituents that typically do not carry the focus accent in non-exclamative utterances (see the demonstrative pronoun DIE in formats 1-4). The present study will narrow its focus to formats 4 and 5, wh-exclamatives with the finite verb in second or final position. The examples presented below involve two of the most common wh-elements (called "w-Elemente" in German) that occur with these types of exclamative in the corpus: wie ('how') and was ('what'). In addition to the syntactic formats 4 and 5 shown in the examples, we also frequently find a minimal, verbless format, consisting of the wh-element and an adjective (e.g. Wie groß! 'How tall!'). The minimal format, too, was included in the analysis.

Studies on exclamations in German are, in large part, based on introspective analyses of invented sentences. The empirical exceptions either draw on exclamations in written language (e.g. Näf 1996; Auer 2016) or apply experimental methods (e.g. Batliner 1988; Batliner/Oppenrieder 1989). Analyses of spontaneous, natural data on this topic are absent in the literature. Therefore, this paper takes a pragmatic approach and addresses exclamatives from an interactional linguistic perspective. While it is assumed that exclamations exist and that they can be realized in different forms - indeed, formats 1-5 all occur in my data - the different points of view regarding the status of exclamations as independent sentence types (i.e. the question of whether 'exclamative sentences' exist or not) are not of interest here.

Regarding work in interactional linguistics more particularly, while much research examines the display of emotion in conversational interaction (cf. Peräkylä/Sorjonen (Eds.) 2012), especially the prosodic design of exaltation (cf. Kallmeyer 1979), affectivity (cf. Couper-Kuhlen 2012; Selting 2012; for the use of so-called sound objects in English, such as $o h$ and $a h$, see Reber 2012), 
and empathy (cf. Kupetz 2015), there seems to be no work that systematically addresses exclamations. In research on semantic and pragmatic aspects of exclamations, their function is often linked to a certain emotional state: the speaker expresses an affect (cf. Schwabe 1992; Larrory 2004), is astonished (cf. Fries 1988), surprised (cf. König/Siemund 2007) or puzzled (cf. Altmann 1987). With respect to the semantics of the wh-exclamatives examined in this paper, they have been shown to express the speaker's surprise about the degree to which a state of affairs in the world applies (vgl. d'Avis 2001; Rett 2009). While these studies adopt the point of view of the speaker, an understanding of exclamations as solely expressing a certain cognitive state of the speaker disregards the role of the listener. If we intend to broaden our understanding of exclamations to include their intersubjective dimension in our pragmatic description, we should look for additional aspects of their usage beyond a purely "expressive" function (cf. Bühler 1934/2011). Based on video recordings of German face-to-face conversations, the present study analyzes exclamations from a context-sensitive social perspective, connecting with research in conversation analysis and interactional linguistics (cf. Couper-Kuhlen/Selting 2001; Ochs et al. (Eds.) 1996). An attempt is made to develop this extended perspective by examining how exclamations are used in an interactive context. What kind of social actions do they carry out? How are they sequentially embedded? In other words, how are exclamations linked to what precedes and what follows in interaction? How are the verbal formats combined with bodily resources, such as gestures, facial expression, gaze direction, or body posture, which may support the expression of exclamativity or help identify the object the exclamation refers to?

The goal of this paper is twofold. First, it attempts to describe the relation of the exclamation to the environment of the speaker and the hearer. It puts forward the hypothesis that exclamations are inherently deictic utterances and shows that the deictic dimension of exclamations can be accounted for by Bühler's (1934/2011) model of the deictic field of language. Second, this paper analyzes the interactive dimension of exclamations. It will demonstrate that exclamations do not constitute social actions themselves, but can be used as resources to carry out different types of actions, such as proffering assessments, noticings, or expressing disagreement. ${ }^{1}$

${ }^{1}$ This contribution presents first results from the ongoing project „Exclamations in interaction: Formal, functional, and visual aspects." I would like to thank the anonymous reviewers and Peter Auer for their helpful comments on a previous version of this paper. I am grateful to Ramona Geng for her help with the transcripts and to Betsy Tremmel for correcting my English. Furthermore, I am indebted to the Baden-Württemberg Stiftung for the financial support of this research project by the Eliteprogramme for Postdocs. 


\section{THE DEICTIC DIMENSION OF EXCLAMATIONS}

According to Bühler's two-field theory (1934/2011), language has a symbolic and a deictic field. With respect to the latter term, Bühler's central idea is that the meaning of deictic elements in language (e.g. demonstrative pronouns) is related to "sensory deictic clues" (1934/2011: 94), such as pointing gestures and their equivalents. Based on this assumption, he distinguishes three different ways of pointing:

"The modi of pointing are various: I can demonstrate ocularly, or I can use the same deictic words anaphorically in speech removed from the situation. Further, there is a third modus, which we shall characterize as imagination-oriented deixis [Deixis am Phantasma, MP]. Nonetheless, one proposition remains phenomenologically valid: although the index finger, the natural tool of ocular demonstration, may well be replaced by other deictic clues, although it is even replaced in speech concerning things that are present, the assistance it and its equivalents provide can never completely cease and simply be dispensed with, not even in anaphora, the most remarkable mode of pointing, the one specific to language. This insight is the pivotal point of our doctrine of the deictic field of language." (Bühler 1934/2011: 94-95)

The first and most basic mode of pointing is "ocular demonstration", that is, referring to an object in the visually accessible environment of the interactants. The other two ways of pointing are also based on the idea of establishing reference to a certain element, but, in contrast to ocular demonstration, they constitute abstract ways of pointing. The second mode is "anaphoric deixis", the very specific case of using language to refer to language itself. When using the third mode of pointing, "Deixis am Phantasma" (translated as "imaginationoriented deixis"), the speaker and the hearer displace themselves to imagined - that is, memorized or fictional - places and point to certain imagined objects, just as they do when demonstrating ocularly within the actual spatial environment. $^{2}$

The following analysis aims to show that the ways in which exclamations establish reference to an object in face-to-face interaction can be categorized according to Bühler's three modes of pointing. In order to clarify the argument of the present paper, it is important to note that in Bühler's model, only certain linguistic elements - prototypical examples are I, here, or now - are deictic and can point in one of the three modes described above. Extending this point of view (although Bühler may not have had in mind such an extension of his theory), this paper hypothesizes that exclamative formats as a whole - conceived of as multimodal constructions including the syntactic and prosodic format, preced-

${ }^{2}$ See Schmitt/Deppermann (2010) and Stukenbrock $(2012,2014)$ for analyses of how imagined spaces are constructed and used as resources in face-to-face interaction. 
ing interjections and vocalizations, as well as accompanying bodily resources - are eo ipso deictic. According to this hypothesis, exclamations are among the deictic resources of a language and point to objects, just like Bühler's deictic elements, in the narrower sense, do. Although exclamations often do contain deictic elements (see the pronoun DIE 'she' in the examples above), their deictic force as a whole is not dependent on these items. Exclamations are deictic because they are resources for constructing stance towards objects, primarily towards objects in the immediate environment of the speaker and the listener or towards things that have just happened in interaction. These are inherently referential acts that require "pointing" to something that is present in the communicative situation. It is this referentiality and their situatedness in the here and now that provide exclamations with a deictic momentum.

One of the most salient properties of exclamations in social interaction has to do with their relation to the surrounding world: every exclamation establishes a reference to a certain element. In what follows, this element the exclamation points to will be called the object of exclamation. The object of exclamation can be, and often is, a visual perception in the immediate environment. In this case, the speaker often faces the task of establishing a common focus of attention with the co-participants on the perceived object. This kind of exclamation corresponds to ocular demonstration, Bühler's first mode of pointing. The object of exclamation can be of a linguistic nature as well. An exclamation can "point" to what somebody has said; it can refer to prior talk. This use of exclamative utterances corresponds to Bühler's second mode of pointing, anaphoric deixis. Additionally, the object of exclamation can be abstract, located only in the imagination of the speaker and the hearer. This type of exclamation corresponds to Bühler's imagination-oriented deixis. On the interactional level, it will be shown to present very specific challenges with respect to a common orientation of the speaker and the hearer towards the object of exclamation. As in these cases, the object of exclamation can only be present in the minds of the speaker and the hearer; the speaker cannot rely on immediate sensory information from the environment in order to establish the effect of exclamativity. This contribution aims to illustrate the deictic dimension of exclamations and to show that the different modes of pointing entail different challenges for interaction.

\section{THE USE OF WH-EXCLAMATIVES IN FACE-TO-FACE INTERACTION}

Based on Bühler's model, this section presents the three deictic dimensions of exclamations which correspond to the three modes of pointing: exclamation as ocular demonstration (3.1), as anaphoric deixis (3.2), and as imaginationoriented deixis (3.3). The three dimensions will be illustrated with case studies from the corpus. 
The following analysis draws on video recordings of German face-to-face conversations, taken from the first season of the reality TV show Big Brother broadcast in 2000. In this show, ten participants spend 100 days together in the Big Brother house, which is equipped with cameras and microphones. Every week, one person must leave the house. The participants interact spontaneously - that is, the show is not scripted - and are involved in different everyday activities, such as cooking, playing games, engaging in sports, discussing, or telling stories.

\subsection{EXCLAMATION AS "OCULAR DEMONSTRATION"}

When analyzing exclamations in conversational interaction, one of the most striking observations is that exclamations often refer to visual perceptions of the immediate environment. It is this observation which is presumably most indicative of the deictic dimension of exclamations: exclamations are anchored in the here and now of the communicative situation. As a consequence, when producing an exclamation, the speaker often needs to call the recipient's attention to an object in the common deictic space using verbal, vocal, and bodily resources.

We will consider two examples for the prototypical usage of exclamations in conversation. In both cases, the exclamation refers to something in the immediate environment that is visually perceived by the speaker. However, the examples differ with respect to the moment in which a common focus of attention is established between the speaker and the listener. While in the first example, a common focus on the object of exclamation already exists when the speaker utters her exclamation, in the second example, this focus is established by the exclamation itself.

In the following extract, the inhabitants of the house enter a room where the producers of the show have arranged several items for the preparation of a Chinese dinner. This surprises the inhabitants. John is the first to walk in and to discover the items, followed by Andrea, Verena, Sabrina, and Jürgen (transcription follows the GAT 2 conventions by Selting et al. 2011, see Appendix, lines indicate the places in the transcript that correspond to the respective Figures): 
(1) Chinese evening

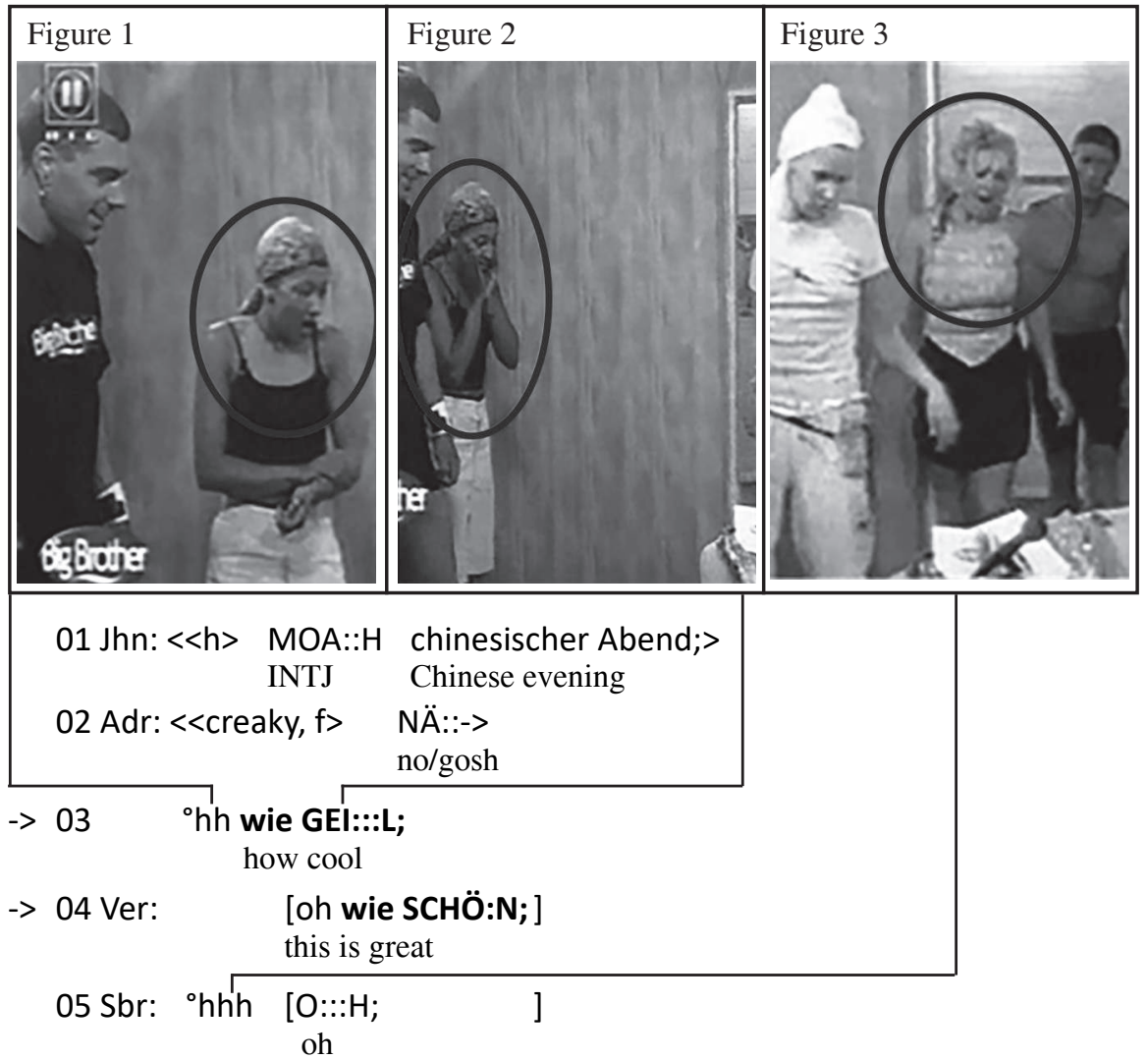

06 Adr: oh mit_m WOK, oh with a wok

07 ich flipp AUS.

I'm freaking out

08 Sbr: oh mit glück dingsdada GLÜCKSkeksen; oh with fortune cookies

-> 09 Ver: ah des_is [ja GEI::L; ]

wow this is so cool

-> $10 \mathrm{Sbr}$ [oh wie SCHÖN;]

oh how great

$11 \mathrm{Jhn}:$ WARte, wait

12 die wolln bestimmt [noch was zu SAgen, ] they probably want to tell us something about it 
John (Fig. 1/Fig. 2, on the left) is the first to enter the room. As he perceives the items, he produces a lengthened and accented interjection $(M O A:: H, 1.01)$ followed by a nominal phrase (chinesischer Abend 'Chinese evening', 1. 01) which can be seen as an interpretation of what the perceived objects are supposed to be used for. This utterance, produced in falsetto, constitutes a positive assessment and initiates a veritable cascade of subsequent aligning assessments. Andrea (Fig. 1/Fig. 2, on the right) enters the room right after John and gazes at the items precisely at the moment in which John starts his turn in 1. 01. At the beginning of Andrea's turn in 1. 02, both John and Andrea are still gazing at the items. That is, they maintain a common focus of attention when Andrea produces her aligning assessment. Her turn consists of several components: the lengthened and accented interjection $N \ddot{A}::$ ('no'/'gosh'), produced with creaky voice, a loud inhaling (see rounded and opened mouth while gazing at the items, Fig. 1), and the verbless wh-exclamative wie GEI:::L ('how cool', 1. 03), accompanied by a hand gesture (Fig. 2). Verena (Fig. 3, on the left) and Sabrina (Fig. 3, in the middle) enter the room right after Andrea and join in with positive assessments, several of them in the form of exclamatives (V2-exclamative: ah des_is ja GEI::L 'wow this is so cool', 1. 09; wh-exclamatives: oh wie SCHÖ:N 'oh how great', 1. 04; oh wie SCHÖN 'oh how great', 1. 10, o::h oh wie WUNderschön 'oh oh how wonderful', 1. 13).

One of the salient properties of exclamations in conversation is that they often occur in clusters. Example (1) provides possible explanations for this observation. With regard to the actions they perform, all the wh-exclamatives constitute assessments, with the inhabitants evaluating the perceived objects very positively. It is important to note that in this semi-mobile setting, the participants enter the room one after another and each of them is performing a "discovery" of objects. Therefore, it is difficult to say whether some of the assessments are to be seen as "second", that is, as directly responding to a previous assessment, or if they should be seen as more independent from each other. Although the exact sequential relationship between the assessments cannot be reconstructed here, it seems plausible to assume that at least the assessments in 1. $09,1.10$, and 1.13 are related to each other because all the participants are co-present in the room and have a common focus on the cooking items while they are uttered. Given the preference for agreement in conversation (cf. Auer/ Uhmann 1982; Pomerantz 1984), it is not surprising to find a cascade of positive assessments in this context. One way of expressing agreement with the previous speaker is to use the same turn design for the action the turn is supposed to implement. Here, the exclamative formats (wh-element + positively evaluating adjective; pronoun + predicative with positively evaluating adjective) indicate a similarly strong scaling of the assessments. But even if we assume that the assessments are more independent from each other and are not primarily 
designed in a similar way for expressing agreement, there is another possible explanation for the clustering of exclamatives: among the variety of possible turn formats for carrying out assessments, the speakers may have chosen exclamative constructions because they are particularly suited for carrying out strong, emphatic assessments.

Besides the use of exclamative formats, the participants draw on the same additional resources to express their aligning positive stance towards the items: interjections, either prosodically integrated, for example as initial elements of exclamations, or as prosodically independent units (e.g. $O \because: H$ 'oh', 1. 05), prosodic means (high pitch and intensity, lengthening of accented syllables, creaky/ falsetto voice), vocal means (loud inhaling, 1. 03, 1. 05), and facial expression (the loud inhalings of Andrea and Sabrina are both accompanied by changes in facial expression characteristic of surprise: a raising of eyebrows and an open, rounded mouth, see Fig. 1 and 3; cf. Darwin 1872; Heath et al. 2012).

With regard to their deictic dimension, all the wh-exclamations in this extract constitute cases of ocular demonstration - the exclamations "point" to the cooking items by virtue of their exclamative format. Due to the semi-mobile setting, incoming participants do not share the focus of attention with the participants already present in the room right from the start. However, when entering the room, they immediately direct their gaze towards the object of exclamation, presumably following the gaze direction and the body posture of the already present participants. For all the wh-exclamatives uttered in example (1), a common focus on the object of exclamation already exists between the speaker and at least one of the co-participants (common focus between Andrea and John in 1. 03, between Andrea, John, Verena, and Sabrina in 1. 04, between Andrea, John, Verena, Sabrina, and Jürgen in 1.10 and 1. 13). Given the common focus, the exclaiming speakers can use a minimal form of the wh-exclamative only consisting of the wh-element and a high degree adjective (1. 03, 04, 10, 13) to refer to the object of exclamation. The same holds for the bodily behavior. Pointing gestures which help to identify the object of exclamation are not necessary and do not occur. Instead, simultaneously with the evaluative adjective of her exclamation, Andrea forms a two-hand-gesture (Fig. 2), consisting of both hands held to the left and the right of her mouth forming a triangle. This gesture is characterized by a specific temporality: it is a "frozen gesture" that is held for several seconds before being released. It is neither a deictic, nor an iconic one, but rather one that supports the expression of exclamativity. Therefore, this gesture seems to be - just like the resources mentioned above - at the service of designing a strong positive assessment. Overall, the participants in this extract make use of an accumulation of resources on the verbal, vocal, and visual levels in order to achieve an effect of maximum exclamativity. 
In the next example of exclamation as ocular demonstration, the exclamation refers to an object that has not yet been interactionally established as a common focus of attention. Therefore, the following example differs from the previous one with respect to the resources used to establish reference to the object of exclamation. In this example, Andrea, Jürgen and Sabrina are sitting at the breakfast table. As part of a teasing activity between Jürgen and Sabrina that had already been going on for a while, Sabrina makes fun of Jürgen by exposing his drooling. For this purpose, she uses different verbal means, including a wh-exclamative, and an accompanying pointing gesture (the direction of the poiting gesture is indicated by an arrow, gaze direction by dashed arrows, cf. also Stukenbrock 2015).

(2) Drooling

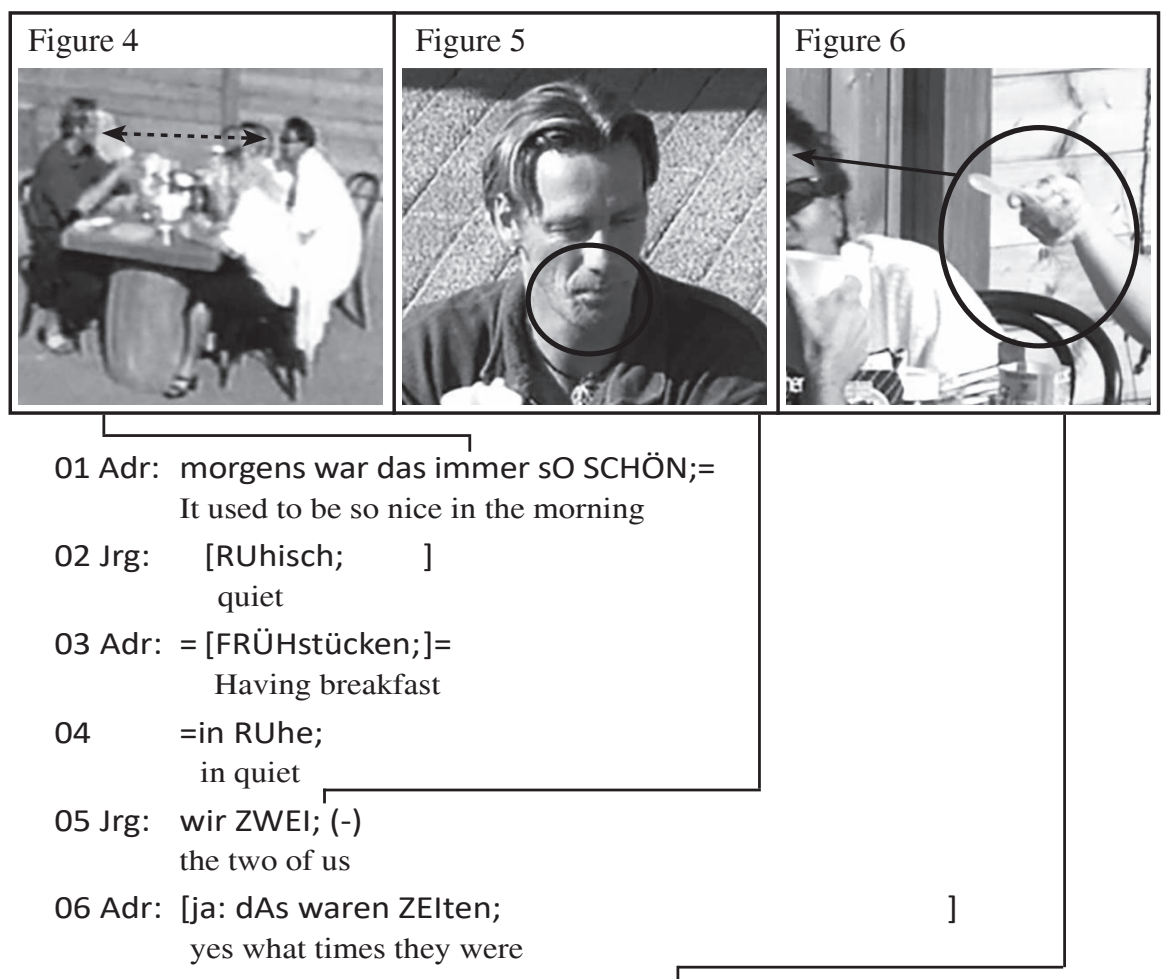

> 07 Sbr: $[<<f>$ BOAH guck mal wat der SAB $<<$ creaky> bert; $>]$

INTJ look how he's drooling

$08 \quad[(($ lacht $))]$

((laughs))

$09 \mathrm{Jrg}: \quad[<<\mathrm{f}>\mathrm{ja}$ aber DU; and how about you

10 dir d' fielen auch die BROCken grade aus_m MUND;>] a couple of chunks have just fallen out of your mouth 
In 1. 01 (morgens war das immer $s O S C H O ̈ N$ 'it used to be so nice in the morning'), as part of a complaint about the frequent and extended quarrels between Jürgen and Sabrina, Andrea refers to the pleasant time before Sabrina's arrival to the Big Brother house (she moved in to replace another inhabitant who had decided to voluntarily leave the house). In the following lines 02-05, she co-constructs, together with Jürgen, a scenario of the past as a quiet time and reaches a conclusion in 1.06 (ja: dAs waren ZEIten 'yes what times they were'). In 1.05 , Jürgen gives the reason why the breakfasts were more peaceful in the past than in the present: there were just 'the two of us' (wir ZWEI), referring to himself and Andrea - the reference of wir ('us') becomes evident in the mutual gaze between Jürgen (Fig. 4, on the left) and Andrea (Fig. 4, on the right). This narrowing down of the "scenario of peace" to only two of the present interactants, while implicitly excluding Sabrina, accuses her of being responsible for the "loss" of quiet breakfasts. In response, Sabrina does not directly react to this accusation by, for example, justifying herself or blaming Jürgen for being responsible for the quarrels himself, but produces an exclamation that introduces a completely new topic. In 1.07 , with a loud voice and starting with the interjection $B O A H$ and the quasi-lexicalized discourse-organizing imperative guck mal 'look' (cf. Proske 2016), Sabrina utters a wh-exclamative (wat der SABbert 'how he's drooling'), producing the last syllable of the verb with creaky voice. Additionally, with the spoon held in her right hand, she performs a pointing gesture to Jürgen's mouth that reaches its stroke on the exclamative accent (Fig 6, 1. 07). While Sabrina subsequently starts to laugh (1. 08), Jürgen replies to this face-threatening remark with a similar, even upgraded, compromising reproach (1. 09-10), blaming Sabrina for having just drooled herself (dir d' fielen auch die BROCKen gerade aus_m MUND 'a couple of chunks have just fallen out of your mouth').

With respect to the question of what prompts this exclamation, it is important to note that Jürgen's production of ZWEI ('two') in 1.05 exhibits an articulatory irregularity. The initial affricate/ts/ is produced with the tongue displaced towards the incisor teeth, leading to a "lisp" sound. This irregularity might be due to drooling, although we cannot be certain because the camera is not directed towards Jürgen at this moment. What we do know, however, is that Jürgen compresses his lips immediately after the articulation of the vowel of ZWEI (Fig. 5). As compressed lips can obviously not be seen as a part of the articulatory movements of a vowel, they may rather be seen as a "repair" movement that hinders the food from falling out of the mouth. Both the lisp sound and the compressed lips provide Sabrina with auditory and visual "evidence" for a suitable object of exclamation on which she can base her reply to Jürgen's initial accusation. With her noticing, Sabrina exposes Jürgen's inadequate social 
behavior (the lack of table manners) and thereby initiates a new sequence which makes relevant some kind of justifying reaction by Jürgen. It is now not she, but Jürgen who is put on the spot. While in example (1), the exclamations carry out assessments, in example (2), the exclamation is doing a noticing which leads to a different sequential development. This shows that exclamations do not have the status of social actions themselves, but are a resource that can be used for different types of actions.

Moreover, in contrast to example (1) where minimal forms of wh-exclamatives (wh-element + adjective) were used, in example (2), the relevant perceived object is not at the focus of attention at the moment the exclamation is uttered. Rather, the exclaiming speaker establishes the focus by the exclamation itself, using several verbal and bodily resources: the discourse-organizing imperative guck mal 'look' which precedes the wh-structure and serves as a focusing directive, the demonstrative pronoun $\operatorname{der}$ ('he') which refers to Jürgen as a person, the verb SABbert ('drooling') which refers to Jürgen's mouth by virtue of its semantics, and the pointing gesture to Jürgen's mouth. To summarize, exclamations that refer to objects which have not yet been interactionally established require different "pointing devices" at the verbal and/or the visual level.

\subsection{EXCLAMATION AS "ANAPHORIC DEIXIS"}

Let us now turn to the second deictic dimension of exclamations, which consists in "pointing" to what somebody has just said. Here, language itself is the object of exclamation.

In the example below, Jürgen, Sabrina, and Andrea talk about the norms of interacting with each other in a relationship. While Jürgen believes it is completely normal to ask your partner to go and get things for you, an opinion supported by Sabrina, Andrea believes that you should not ask your partner to do so, but should get the things you need on your own. 
(3) What is that

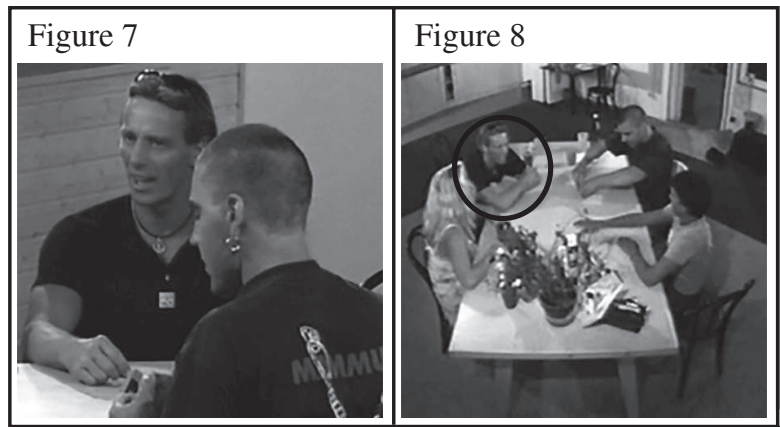

01 Adr: das_is doch selbstverständlich wenn mir was nich PASSTIt is self-evident that if I need something

02 dass ich_s mir dann SELber holen gehe. that I go and get it myself then

$03(-)$

$(-)$

04 da sag ich [doch nich] geh mal und HOL mir. of course I don't say go and get it for me

$05 \mathrm{Sbr}$ : [hä? ] huh?

$->06$

$->07$ Jrg:

08 Adr:
(1.7) $<<h>$ was_is $<<\mathrm{h}>$ what is

09

DAT [dann;
that ADV>

[boah wat_is] DAT denn [ey.]

INTJ what is that ADV INTJ

[na ] KLA:R.

But of course

ich schick doch nich_n Andern wenn ich gerne was HAben will. I surely don't send somebody else when I'd like to have something (.) da hol_ich mir doch SELber meine SAchen. (-) Then I go and get my stuff myself

During the conversation preceding this extract, it has become clear that Jürgen's and Sabrina's opinions differ from Andrea's. Starting in 1. 01, Andrea explains her position using a conditional construction and reaches a possible turn completion point in the end of 1. 02. As there is no reaction from her coparticipants during the short pause (1. 03), she expands her turn in 1. 04. While the apodosis in 1.02 expresses what is 'self-evident' (selbstverst $\ddot{A}$ ndlich, 1. 01) for her, that is, what one should do in her view, the turn expansion in 1.03 ('of course I don't say go and get it for me') states what one should not do according to her, that is, explicitly denies Jürgen's and Sabrina's opinion, which 
runs contrary to hers. During this expansion, Sabrina and Jürgen already indicate their lack of understanding of Andrea's position: Sabrina uses the repair initiator hä ('huh', 1. 05), and Jürgen uses his facial expression (open mouth, slightly lowered eyebrows, Fig. 7). Both resources project upcoming disagreement. After Andrea has finished her turn, quite a long pause of 1.7 seconds emerges (1. 06), which constitutes another indication of an upcoming dispreferred action. By withholding their turns, Jürgen and Sabrina orient to the conversational preference for agreement and give Andrea a last chance to revise her position. As this does not happen, Sabrina produces a first wh-exclamation (was is DAT dann 'what is that', 1. 06) that overlaps with a second wh-exclamation by Jürgen (boah wat is DAT denn ey 'what is that', 1. 07), who simultaneously leans forward and puts his elbows on the table (Fig. 8). Both exclamations express disagreement with Andrea's opinion, which contrasts with that of the speakers. Andrea's reaction shows that she, indeed, interprets the wh-constructions as referring to her previous statement. Immediately and in overlap with the second exclamation, she insists on her own position (na KLA:R 'but of course', 1. 08), followed by a justification (1. 09 and 10). Both components are typical in the context of disagreement.

With respect to the deictic dimension, the exclamations in example (3) differ from the two examples in the previous section. In this example, the object of exclamation is not visually perceivable; it is impossible to point at it in the literal sense, that is, to demonstrate ocularly. The object of exclamation is not visual, but linguistic in nature. Both exclamations refer to Andrea's preceding talk in which she presents her position. Therefore, instead of using a pointing gesture like in example (2), the exclaiming speakers need to resort to anaphoric deixis in order to refer to the relevant object. They need, to use Bühler's words (1934/2011: 95), "the mode of pointing specific to language". In this example, in both exclamations a deictic word (the demonstrative pronoun DAT 'that', 1. 06 and 07 ) is used to explicitly establish reference the object of exclamation. However, as exclamative formats as a whole are deictic, this is not necessary for an exclamation to function as anaphoric deixis. Exclamations with no deictic items, such as 'how ridiculous', can also be used to refer to something that has just been said. 


\subsection{EXCLAMATION AS "IMAGINATION-ORIENTED DEIXIS"}

In the examples analyzed in the previous two sections, we have seen how exclamations point to visually perceivable (3.1) and to linguistic objects of exclamation (3.2). From a cognitive perspective, linguistic objects of exclamation

are - just as spoken language in general - transitory in nature. In order to be able to refer to them with an exclamation, they must still be present in the minds of the speaker and the listener after the acoustic signal of the spoken word has disappeared. This is in contrast to cases of ocular demonstration, where a visual object of exclamation is sensorily accessible at the time the exclamation is uttered. The third deictic dimension of exclamations, Bühler's Deixis am Phantasma ("imagination-oriented deixis"), is similar to anaphoric deixis in that a representation in the minds of the interactants is necessary for the "pointing" to function. However, in Bühler's psychological terms, while linguistic information that can be referred to anaphorically is to be found in the "immediate retention", that is, the working memory, the long-term memory is involved in imagination-oriented deixis:

"When the psychologist comes across performances of so-called immediate retention, he looks for similar performances in the realm of retention that is no longer immediate but mediate, that is, fully-fledged memories and constructive phantasy. [...] We will call this third mode of pointing imagination-oriented deixis. Thus, ocular demonstration must be distinguished from anaphora and imaginationoriented deixis." (Bühler 1934/2011: 139-140)

In the following, we will examine an exclamation that points to an imagined object, meaning the object of exclamation is neither visually accessible nor accessible in the immediate retention of what has just been said. Rather, the listeners need to "look" into their memories in order to establish a common focus.

In example (4), Manu (on the left), Joana (in the middle), and Kerstin (on the right) have made themselves comfortable in a "camp" consisting of blankets and pillows and are discussing a party that took place in the Big Brother house some days ago. It is important to know that Kerstin and another inhabitant, Alex, hooked up the night following the party. 
(4) Party

\begin{tabular}{|l|l|l|}
\hline Figure 9 & Figure 10 & Figure 11 \\
\hline & &
\end{tabular}

01 Man: oah das war ne GUte idee:. $\mathrm{h}^{\circ}$ INTJ that was a good idea

02 Ker: ja VOLL; (--) yes totally

03 voll geMüTlich; totally cozy

04 Joa: voll das CAMP; totally a camp

05 das LAger; (.) a bed

oah wie dUnkel es auf der PARty das letzte mal war.=ne,

INTJ how dark it was at the party last time wasn't it

07 also [ich] mein de' di' ${ }^{\circ} \mathrm{h}$ bei den letzten LIEdern; well I mean during the last songs

08 Ker: [ja]

09 Man: B [O::AH ]

yes
y:
$:$ AH

10 Ker: [ja ] yes

11 Joa: [hm_hm] hm_hm

12 Ker: COOL; (--) cool

13 da war_s richtig- (--) That was really

14 Man: des ham se doch nur erwartet dass du und alex auf die TANZfläche gehen. (0.5)

They only expected you and Alex to go to the dancefloor

15 Joa: hm_hm? (.) hm_hm

16 Man: DESwegen ham se_s gemacht; (.)

That's why they did it 
After having asserted to each other what a good idea it was to build the camp and how comfortable it is (1. 01-05), Manu initiates a new topic (they had not been discussing this topic in the entire preceding conversation) using the interjection oah followed by a wh-exclamative (wie dUnkel es auf der PARty das letzte mal war 'how dark it was at the party the last time', 1. 06). While the participants are not gazing at each other in the beginning of the exclamation (Fig. 9), Manu establishes mutual gaze with Kerstin who, therefore, is to be seen as the addressee of Manu's exclamation. Interestingly, Joana also gazes at Kerstin (without having previously looked at Manu and without following her gaze direction), showing that she, independently, has interpreted Manu's exclamation as being directed at Kerstin. Kerstin, however, does not immediately respond to the exclamation when Manu reaches a possible turn completion point after the question tag (ne 'isn't it', 1. 06) which explicitly makes relevant a response. This is in contrast to examples (2) and (3), in which the recipient of an exclamation promptly reacts to the exclamation (the exclamations in example (1) seem not to be directed towards a specific recipient), with the type of reaction being dependent on the action carried out by the exclamation.

As Kerstin does not take the turn, Manu delivers a prepositional phrase that specifies the exclamative utterance (also ich mein de di $^{\prime}{ }^{\circ} \mathrm{h}$ bei den letzten LIEdern 'well I mean during the last songs', 1. 07). More specifically, it is the object of exclamation which is specified here: Manu refers no longer to the high degree of darkness at the party in general, but to the high degree of darkness during the last songs. As during this elaboration Kerstin only provides a minimal response (ja 'yes', 1. 08), Manu extends her turn beyond a next possible completion point, producing the accented interjection $B O:: A H$ (1. 09), emphasizing the noteworthiness of the observation presented in the exclamation. While uttering this interjection, Manu establishes mutual gaze with Joana, who produces a response token $\left(h m \_h m, 1.11\right)$, which may be seen as an indication of some kind of shared knowledge with respect to the situation referred to. In overlap with the interjection and Joana's response token, Kerstin starts an attempt to respond to the exclamation, delivering another minimal response ( $\mathrm{ja}$ 'yes', 1. 10), followed by an evaluating adjective (COOL 'cool', 1. 12) and the beginning of a syntactically more complex assessment (da war_s richtig 'That was really', 1. 13). However, Kerstin interrupts her predicative construction at a point where another evaluating adjective is syntactically projected. Manu neither helps Kerstin by co-constructing her turn, nor continues to wait in the end of 1.13 until she finishes the assessment herself. Instead, Manu presents the solution to the riddle of what was so remarkable regarding the darkness: in her view, the producers of the TV show wanted to make Kerstin and Alex dance 
together (1. 14), presumably because Manu believes the producers had realized that they were attracted to each other. By not reacting to Kerstin's beginning of an assessment, she indicates that she does not accept an assessment as an adequate response to her exclamation, meaning she does not categorize her own exclamation as a first assessment that makes relevant a second assessment. After Joana's affirmation of Manu's opinion ( $\left.h m \_h m, 1.15\right)$, Manu emphasizes the "hidden motive" for the darkness (DESwegen ham se_s gemacht 'That's why they did it', 1. 16). By presenting this solution, her exclamation becomes retrospectively accountable: Manu herself treats it as an "observation in need for explanation", not as an assessment.

This exclamation is similar to the one in example (2) with respect to the fact that speakers are pointing to a completely new object that is introduced by the exclamation itself. In example (4), however, the object of exclamation (the high degree of darkness at a party which all participants had attended), cannot be pointed to in the same way as the "drooling" in example (2). Although, in a certain manner, the object of exclamation consists of a visual perception, it is not an immediate perception directly accessible in the environment as was the case in the examples of ocular demonstration (1) and (2), but a mediate perception experienced in the past, an imagined space which can only be accessed indirectly through a representation in long-term memory. The absence of an adequate recipient reaction to this exclamation, which could not be observed in the other examples, gives rise to the hypothesis that exclamations which point at abstract, imagined objects pose specific challenges for the listener. An alternative interpretation for the lack of an adequate recipient reaction may have to do with the delicate and potentially face-threating topic (Kerstin and Alex's hookup) that Manu is indirectly introducing and that Kerstin may be unwilling to discuss. Based on this case study alone, it is not possible to claim that imagination-oriented deixis is indeed cognitively more challenging for recipients. What can be said, however, is that imagination-oriented deixis occurs less frequently in the current collection of exclamations and seems to be used for specific types of actions.

This example indirectly provides evidence for the assumption that exclamations always happen in the here and now and, therefore, supports the hypothesis that exclamations as a whole are always deictic. This example is highly marked because despite explicitly referring to a remembered space (cf. the past tense of the verb war "was', 1. 06), the exclamative format "pretends" that something is happening in the here and now (cf. the interjections oah, 1. 06, and $B O:: A H, 1.09)$. 


\section{PRELIMINARY CONCLUSION AND OUTLOOK}

The purpose of this paper was, first, to introduce the hypothesis that exclamations as a whole are inherently deictic phenomena, regardless of whether they contain deictic linguistic items in the narrower sense. Overall, the analyses show that the common assumption that exclamations refer to something that is unexpected (cf. d'Avis 2013: 171) can be specified, at least for their use in face-to-face-conversation. Exclamations refer to objects that: 1) are sensorily, most often visually, perceived; 2) have just been said; or 3) exist in the imagination. Ocular demonstration seems to be the most natural way of producing an exclamation. The reason for our preference to exclaim at visual objects may have to do with the dominance of visual perception over other human senses, a claim that has been discussed in comparative linguistic work (cf. San Roque et al. 2015). Anaphoric deixis is related to ocular demonstration in that the object of exclamation is immediate sensory information, that is, the acoustic linguistic signal. Imagination-oriented deixis seems to be more peripheral in exclamations. In these cases, the object of exclamation is not present in the here and now of the immediate environment and, therefore, cannot be made accessible to the recipients in the same natural way.

Going beyond existing analyses of the expressive function of exclamations from the point of view of the speaker, the second aim of this contribution was to analyze the interactive dimension of exclamations. As the examples show, exclamations do not have the status of social actions by themselves, but are used as communicative resources for carrying out different types of actions, such as assessments or noticings. That is, exclamations are not always "doing" the same thing, but possess the flexibility to serve different interactive purposes.

Several important questions concerning the interactive dimension of exclamations could only be touched upon in this paper and must be left to future research. First, when and through what means is the focus on the object of exclamation interactionally established? The focus may have already been established previously, or it may be established by the exclamation itself. Are there syntactic differences between the two cases? Do we find more minimal syntactic formats (see example 1) in the former than in the latter case? If the exclamation itself establishes the focus, how is the interplay between the different components of the exclamation (syntactic and prosodic format, preceding interjections and vocalizations, and bodily resources) organized? Second, concerning the expression of exclamativity, how is the division of labor between the different components of exclamations organized? We have seen that bodily displays (e.g. the "frozen gesture" and the facial expression in example 1) can support the expression of exclamativity, but what "exclamative force" do they have compared to, for example, the syntactic structure, the exclamative accent, or a preceding 
interjection? More qualitative research on the use of exclamations in face-toface interaction that draws on a larger database will be necessary to address, and maybe answer, some of these questions.

\section{REFERENCES}

Altmann, Hans (1993): Satzmodus. In: J. Jacobs, A. von Stechow, W. Sternefeld, and Th. Vennemann (Eds.): Syntax. Ein internationales Handbuch zeitgenössischer Forschung. Berlin: de Gruyter, 1006-1029.

Altmann, Hans (1987): Zur Problematik der Konstitution von Satzmodi als Formtypen. In: J. Meibauer (Ed.): Satzmodus zwischen Grammatik und Pragmatik. Tübingen: Niemeyer, 22-56.

Auer, Peter / Uhmann, Susanne (1982): Aspekte der konversationellen Organisation von Bewertungen. In: Deutsche Sprache 1, 1-32.

Auer, Peter (2016): "Wie geil ist das denn?" Eine neue Konstruktion im Netzwerk ihrer Nachbarn. In: Zeitschrift für Germanistische Linguistik 44 (1), 69-92.

Batliner, Anton (1988): Der Exklamativ: mehr als Aussage oder doch nur mehr oder weniger Aussage? Experimente zur Rolle von Höhe und Position des F0-Gipfels. In: H. Altmann (Ed.): Intonationsforschungen. Tübingen: Niemeyer, 243-271.

Batliner, Anton / Oppenrieder, Wilhelm (1989): Korpora und Auswertung. In: H. Altmann, A. Batliner, and W. Oppenrieder (Eds.): Zur Intonation von Modus und Fokus im Deutschen. Tübingen: Niemeyer, 281-330.

Bühler, Karl (1934/2011): Theory of language. The representational function of language. Translated by Donald Fraser Goodwin, in collaboration with Achim Eschbach. Amsterdam/Philadelphia: Benjamins.

Couper-Kuhlen, Elizabeth (2012): On affectivity and preference in responses to rejection. In: Text and Talk 32 (4), 453-476.

Couper-Kuhlen, Elizabeth / Selting, Margret (2001): Introducing Interactional Linguistics. In: M. Selting and E. Couper-Kuhlen (Eds.): Studies in Interactional Linguistics. Amsterdam: Benjamins, 1-22

Darwin, Charles (1872): The expression of the emotions in man and animal. London: John Murray.

d'Avis, Franz-Josef (2001): Über w-Exklamativsätze im Deutschen. Tübingen: Niemeyer.

d'Avis, Franz-Josef (2013): Exklamativsatz. In: J. Meibauer, M. Steinbach, and H. Altmann (Eds.): Satztypen des Deutschen. Berlin: de Gruyter, 171-201.

Fries, Norbert (1988): Ist Pragmatik schwer! - Über sogenannte ,Exklamativsätze‘ im Deutschen. In: Sprache und Pragmatik 3, 1-18. 
Heath, Christian / Vom Lehn, Dirk / Cleverly, Jason / Luff, Paul (2012): Revealing surprise. The local ecology and transposition of action. In: A. Peräkylä and M.-L. Sorjonen (Eds.): Emotion in Interaction. Oxford: Oxford University Press, 212-234.

Kallmeyer, Werner (1979): “(expressif) eh ben dis donc, hein’ pas bien' “ - Zur Beschreibung von Exaltation als Interaktionsmodalität. In: R. Kloepfer, A. Rothe et al. (Eds.): Bildung und Ausbildung in der Romania. München: Fink, 549-568.

König, Ekkehard / Siemund, Peter (2007): Speech act distinctions in grammar. In: T. Shopen (Ed.): Language Typology and Syntactic Description. Cambridge: Cambridge University Press, 276-324.

Kupetz, Maxi (2015): Empathie im Gespräch - Eine interaktionslinguistische Perspektive. Tübingen: Stauffenburg Linguistik.

Larrory, Anne (2004): Mehr oder weniger exklamativ? Wie kann man Exklamation definieren? In: M. Krause and N. Ruge (Eds.): Das war echt spitze! Zur Exklamation im heutigen Deutsch. Tübingen: Stauffenburg, 1-13.

Näf, Anton (1987): Gibt es Exklamativsätze? In: J. Meibauer (Ed.): Satzmodus zwischen Grammatik und Pragmatik. Tübingen: Niemeyer, 140-160.

Näf, Anton (1996): Die w-Exklamativsätze im Deutschen - zugleich ein Plädoyer für eine Rehabilitierung der Empirie in der Sprachwissenschaft. In: Zeitschrift für Germanistische Linguistik 24, 135-152.

Ochs, Elinor / Schegloff, Emanuel A. / Thompson, Sandra A. (Eds.) (1996): Interaction and Grammar. Cambridge: Cambridge University Press.

Oppenrieder, Wilhelm (1988): Intonation und Identifikation. Kategorisierungstests zur kontextfreien Identifikation von Satzmodi. In: H. Altmann (Ed.): Intonationsforschungen. Tübingen: Niemeyer, 153-168.

Peräkylä, Anssi / Sorjonen, Marja-Leena (Eds.) (2012): Emotion in Interaction. Oxford: Oxford University Press.

Pomerantz, Anita (1984): Agreeing and disagreeing with assessments: some features of preferred/dispreferred turn shapes. In: J. M. Atkinson and J. Heritage (Eds.): Structures of social action. Cambridge: Cambridge University Press, 57-101.

Proske, Nadine (2016): Zur Funktion und Klassifikation gesprächsorganisatorischer Imperative. Presentation, 19. Arbeitstagung zur Gesprächsforschung, Institut für Deutsche Sprache, Mannheim, March 16-18, 2016.

Reber, Elisabeth (2012): Affectivity in interaction. Sound objects in English. Amsterdam/Philadelphia: Benjamins.

Rett, Jessica (2009): A degree account of exclamatives. In: Semantics and Linguistic Theory XVIII, 601-618. 
Rosengren, Inger (1992): Zur Grammatik und Pragmatik der Exklamation. In: I. Rosengren (Ed.): Satz und Illokution, Tübingen: Niemeyer, 263-306.

Rosengren, Inger (1997): Expressive sentence types - A contradiction in terms. The case of exclamation. In: T. Swan and O. J. Westvik (Eds.): Modality in Germanic languages. Historical and comparative perspectives. Berlin: de Gruyter, 151-184.

San Roque, Lila / Kendrick, Kobin H. / Norcliffe, Elisabeth / Brown, Penelope / Defina, Rebecca / Dingemanse, Mark / Dirksmeyer, Tyko / Enfield, NJ / Floyd, Simeon / Hammond, Jeremy / Rossi, Giovanni / Tufvesson, Sylvia / van Putten, Saskia / Majid, Asifa (2015): Vision verbs dominate in conversation across cultures, but the ranking of non-visual verbs varies. In: Cognitive Linguistics 26 (1), 31-60.

Schmitt, Reinhold / Deppermann, Arnulf (2010): Die multimodale Konstitution eines imaginären Raums als interaktive Problemlösung. In: A. Deppermann and A. Linke (Eds.): Sprache intermedial. Stimme und Schrift, Bild und Ton. Berlin/New York: de Gruyter, 199-242.

Schwabe, Kerstin (1992): Doch eine grammatische Kategorie „Exklamativ“?. In: Zeitschrift für Phonetik, Sprachwissenschaft und Kommunikationsforschung 45, 17-29.

Selting, Margret (2012). Complaint stories and subsequent complaint stories with affect displays. In: Journal of Pragmatics 44, 387-415.

Selting, Margret / Auer, Peter / Barth-Weingarten Dagmar / Bergmann, Jörg / Bergmann, Pia / Birkner, Karin / Couper-Kuhlen, Elizabeth / Deppermann, Arnulf / Gilles, Peter / Günthner, Susanne / Hartung, Martin / Kern, Friederike / Mertzlufft, Christine / Meyer, Christian / Morek, Miriam / Oberzaucher, Frank / Peters, Jörg / Quasthoff, Uta / Schütte, Wilfried / Stukenbrock, Anja / Uhmann, Susanne (2011): A system for transcribing talk-in-interaction: GAT 2. Translated and adapted for English by Elizabeth Couper-Kuhlen and Dagmar Barth-Weingarten. In: Gesprächsforschung - Online-Zeitschrift zur verbalen Interaktion 12, 1-51.

Stukenbrock, Anja (2012): Imagined spaces as a resource in interaction. In: Bulletin Suisse de Linguistique Appliquée 96, 141-161.

Stukenbrock, Anja (2014): Pointing to an 'empty' space: Deixis am Phantasma in faceto-face interaction. In: Journal of Pragmatics 74, 70-93.

Stukenbrock, Anja (2015): Deixis in der Face-to-Face-Interaktion. Berlin/Boston: de Gruyter.

Zaefferer, Dietmar (1983): The semantics of non-declaratives: Investigating German Exclamatories. In: R. Bäuerle, C. Schwarze, and A. von Stechow (Eds.): Meaning, use, and interpretation of language. Berlin: de Gruyter, 466-490.

Zifonun, Gisela / Hoffmann, Ludger / Strecker, Bruno et al. (1997): Grammatik der deutschen Sprache. 3 Bde. Berlin: de Gruyter. 


\section{APPENDIX}

Transcription conventions (cf. Selting et al. 2011)

[ ]

overlap and simultaneous talk

[ ]

${ }^{\circ} \mathrm{h} /{ }^{\circ} \mathrm{hh} /{ }^{\circ} \mathrm{hhh} \quad$ inbreath of appr. 0.2-0.5 / 0.5-0.8 / 0.8-1.0 sec. duration

(.) micro pause, estimated, up to $0.2 \mathrm{sec}$. duration appr.

$(-) /(--)$ estimated pauses of appr. 0.2-0.5 / 0.5-0.8 sec. duration

und_äh assimilations within units

äh hesitation marker

hehe

syllabic laughter

hm_hm

continuer, bi-syllabic tokens

(solche)

assumed wording

$->$

refers to a line of transcript relevant in the argument

$=$ fast, immediate continuation with a new turn or segment (latching)

$: /:: /::$ lengthening, by about $0.2-0.5 / 0.5-0.8 / 0.8-1.0 \mathrm{sec}$. cut-off by glottal closure

SYLlable focus accent

sYllable secondary accent

? rising to high (final pitch movement of intonation phrase) rising to mid (final pitch movement of intonation phrase) level (final pitch movement of intonation phrase) falling to mid (final pitch movement of intonation phrase) falling to low (final pitch movement of intonation phrase) $<<\mathrm{f}>\quad$ forte, loud (with scope) $<<$ creaky $>>\quad$ glottalized (with scope) 